\title{
木材チップエ 業*
}

米 沢 保 正**

\section{は しがき}

近年とみに急增してきた材の不足の波にのって， いわゆる材チップ工業が誕生してから本年で7年目 を迎方る汇至った。その生産量も 36 年度には $450 \sim 5$ 00 万 $\mathrm{m}^{3}$ が見込安れ，これは同年度に淤るる全パルプ 用材量の約 $1 \frac{3}{3}$ 洋し，自由貿易を控えた今日，その重 要性から第 3 の原木とまで音われ, パルプ原料として, 広葉樹と共沉救断主的存在にまでのし上ってきた。そ

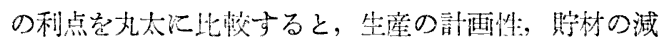
少，原料購入資金つ減少々效率運用，腐朽などによる 原木ロスの減少, 検収要員と施設の節減, 管理経費の 節約など著しいもので，その他樹皮処理問題，騒音減 少等の利点も兌逃しにできないところである。

以上はチップ需要者側からみた利点であるが，また 供給者側汇も利益至もたらした。副生材利用の兼業生

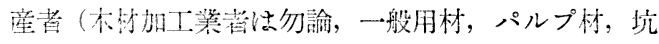

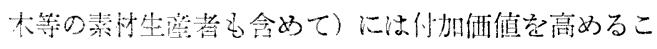
とによる利益，年間平均した焦㦃が行なえることなど

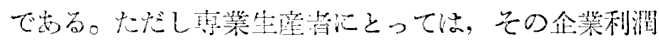
のみが頼りであって，その他の妙味何等考光られな い。今後チップ工業が，その原料として低洒维忉の加 工に限定された場合，ぞこ亲で伸びるか。今日瞄汇一 部の地方で各原料嚾, 往って原料高となって行き詰り を来したとみられ，少なくとも針葉樹（北海檤意除い

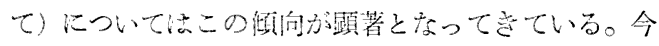

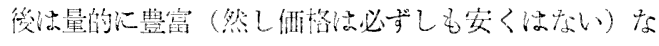

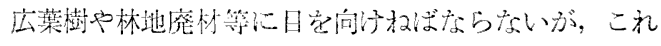
もチップ洒格との閶連においてどこまで伸び得られる か，一にチップ酒格に左右されるもので，これ虫な 丸太事情に支限される媈命に岕るので，良来チップ工 業がたどってきたような順調な步及を今後も続けるこ

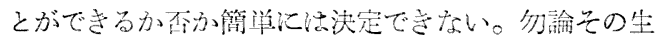

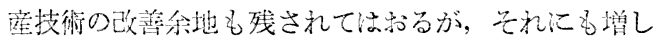
て，貿易自由化による王迫材料が前途をはばんでいる ように考光る。パルプ工業にとって原木間題が最も重

* 原衡受的 37. 2. 16

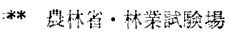

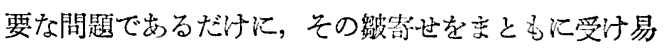
く，その昜合，大企業による小企業の压迫は免れない ところである。今後に拈けるチップ工業の技術的, 経 営的在り方は極めて重要であって, それと同時に, 需 要者側のチップ工業に対する理解と援助が必須要件と 考觉る。以下その生産実態の概略を述べ, 問題点につ いて順を追ってふれてみよう。

\section{1. チップ原料}

チッップ工業原杢消費の歴大は, 当時最も不足の甚し かった針葉樹特にマッの使用に始った。パルプ原料を 多量汇移入する静岡県, マッ生産の最多である広島県 等汇まずチップ工業が生れ，いずれも針葉樹製材工場 廃村を原料とした。その後次第にチップ工業の鄫及と 広域化にともなって種々な樹種, 䅣々な形態のものが 原料化されてきた。今チップ生産量, 使用原料の推移 を揭げると第 1 ，第 2 表の通りである。

第 I表 木忉チップ生産量の推移 (浽位: $1009 \mathrm{~m}^{3}$ )

\begin{tabular}{|c|c|c|c|c|c|c|}
\hline 年度 & 31 & 32 & 33 & 34 & 35 & 36 \\
\hline 生詹数量 & 49 & 560 & 934 & 2,184 & 3,370 & 4,529 \\
\hline 生産指数 & 10 & 114 & 191 & 446 & 688 & 924 \\
\hline 前年刘比\% & - & 1,143 & 167 & 236 & 154 & 134 \\
\hline
\end{tabular}

針悉樹刘広葉樹の比率学又ると逐年広葉樹が增加し， 現在 65:35 となってきている。㓜論針㗛樹も䋓対量に 扣いては連年增加しているが，父机以上に広菜樹チッ

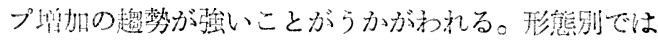

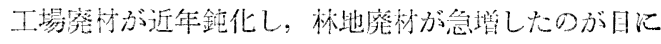
つく。これ浊工場廃惊の利用はかなり集䄪的に行われ て来た反面，林地残林汇怡令後大いに期待され，只れ に対する依存度が高まりつつあること示している。

次に原料検取法についてのベる。チップ原糊中丸太 については一般に未日検知法が行われているが，時に

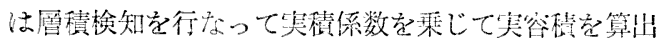
する方法もとられている。いずれの方法も正確な実容 積を得ることは困難である。結束した小径木，背板等 の場合（マキ）は予めその実積係数を求めてお小て， 
第2表 チップ原料消費量の推移 （単位： $1000 \mathrm{~m}^{3}$ )

\begin{tabular}{|c|c|c|c|c|c|c|c|c|c|}
\hline \multirow{2}{*}{\multicolumn{2}{|c|}{ 区 分 }} & \multicolumn{2}{|c|}{33} & \multicolumn{2}{|c|}{34} & \multicolumn{2}{|c|}{35} & \multicolumn{2}{|c|}{36} \\
\hline & & 数量 & 比率 & 数量 & 比率 & 数量 & 比率 & 数量 & 比率 \\
\hline \multirow{2}{*}{ 針 } & \multirow{2}{*}{$\begin{array}{l}\text { 除間伐材小径木 } \\
\text { 木材加工工場廃材 }\end{array}$} & 83 & $\begin{array}{r}\% \\
4\end{array}$ & 102 & $\begin{array}{r}\% \\
5\end{array}$ & 564 & $\begin{array}{l}\% \\
17\end{array}$ & 630 & $\begin{array}{r}\% \\
14\end{array}$ \\
\hline & & 542 & 56 & 957 & 42 & 1,194 & 35 & 1,360 & 30 \\
\hline \multirow{2}{*}{ 葉 } & 林 地 残 材 & 171 & 17 & 355 & 16 & 542 & 16 & 703 & 16 \\
\hline & $\checkmark$ & 85 & 9 & 175 & 8 & 118 & 4 & 146 & 3 \\
\hline \multirow{2}{*}{ 樹 } & の & 21 & 2 & 62 & 3 & 67 & 2 & 85 & 2 \\
\hline & 計 & 857 & 88 & 1,651 & 74 & 2,485 & 74 & 2,924 & 65 \\
\hline \multirow{2}{*}{ 広 } & 除間伐材小径木 & 50 & 4 & 160 & 7 & 290 & 8 & 439 & 9 \\
\hline & 木材加工工場廃材 & 41 & 5 & 273 & 12 & 369 & 11 & 455 & 10 \\
\hline \multirow{2}{*}{ 葉 } & 林 地 残 材 & 6 & 1 & 97 & 4 & 133 & 4 & 538 & 12 \\
\hline & & 10 & 1 & 41 & 2 & 76 & 2 & 134 & 3 \\
\hline \multirow{2}{*}{ 樹 } & そ & 5 & 1 & 33 & 1 & 23 & 1 & 37 & 1 \\
\hline & 計 & 112 & 12 & 604 & 26 & 891 & 26 & 1,603 & 35 \\
\hline \multirow{4}{*}{ 合 } & 除間伐材小径木 & 88 & 9 & 262 & 12 & 854 & 25 & 1,069 & 23 \\
\hline & 木材加工工場廃材 & 583 & 60 & 1,230 & 54 & 1,563 & 46 & 1,815 & 40 \\
\hline & 林 地 残 材 & 177 & 18 & 452 & 20 & 675 & 20 & 1,241 & 28 \\
\hline & $\checkmark$ & 95 & 10 & 216 & 10 & 194 & 6 & 280 & 6 \\
\hline \multirow{2}{*}{ 計 } & そ & 26 & 3 & 95 & 4 & 90 & 3 & 122 & 3 \\
\hline & 計 & 969 & 100 & 2,255 & 100 & 3,376 & 100 & 4,527 & 100 \\
\hline
\end{tabular}

註：36年度は計画量

実際の取引きには何束で 1 石というような, 束数のみ を数觉て検收するものが多い。1 例をあげると小径木 束で長さ 2 尺, 直径 0.75 尺の場合は実積係数として 0.5 を採用し， 1 束 $=0.044$ 石, 従って 23 束 $=1$ 石, 製材薪の長さ 1.6 尺, 直径 0.73 尺の場合の実積係数は, $0.4,1$ 束 $=0.027$ 石, 従って 37 束 $=1$ 石として报われ ている。

その他不規則形状のものについては更に概略的で, 3 輪車（枠組み）1台で何石といった大雑杷な报い方 が一般である。

極めて進歩した検知法として重量検知を行なってい

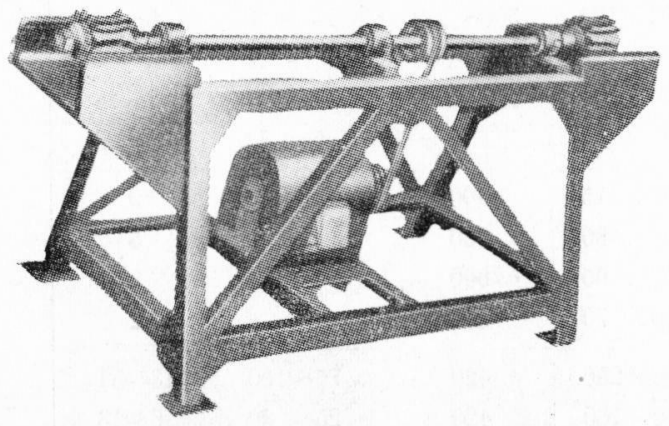

(a) カットパーカー
るものもあるが一般化しては いない。

これら原料検知が一般に極 めて不正確なため管理, 原価 計算等に不便と不正確をまね いている。今後大い研究を 要すべき事項の一つである。

\section{2. 剥皮}

パルプ工場で行なら丸太の 剝皮に比較して，一般飞製品 チップの一定量当りの剝皮量 が多いことと, 剝皮刘象物が 不整形, 細薄物である点に著 しい差がある。従って丸太用 バーカーをとのま使用する ことができないので小型バー カーを取り入れている。これ にはドラムバーカー, カット バーカーが一般で, な牧手剝 ぎもかなり一般に行なわれ

ている。チップ生産量, 形状

に応じて方法を選択すべきで
ある。ドラムパーカーの大型のものになるとチップ工 場諸機械中最も高価なものとなるので, この剥皮工程 が5まく, 安く行ない方られるよ5事前調査と使いこ なしが必要である。

剥皮能率は樹種, 形状, 季節, 乾燥度等によって差 があるが 1 例を示すと次のようになる。

アカマツを原料とし, 手剥ぎの場合に, 小径木で1.5

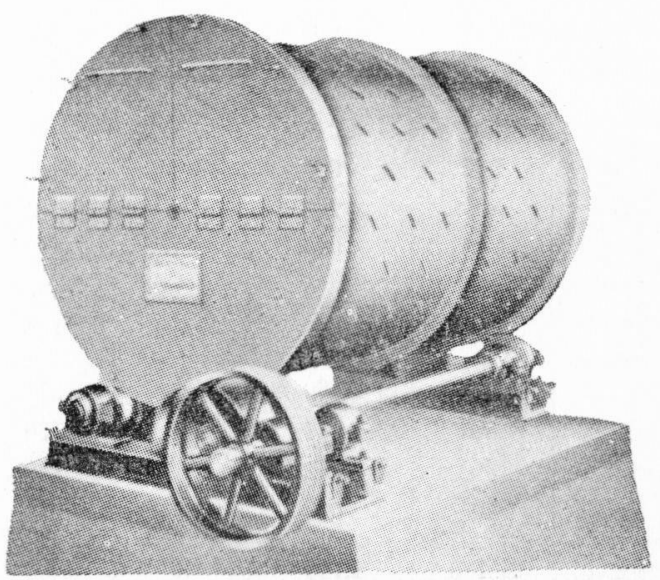




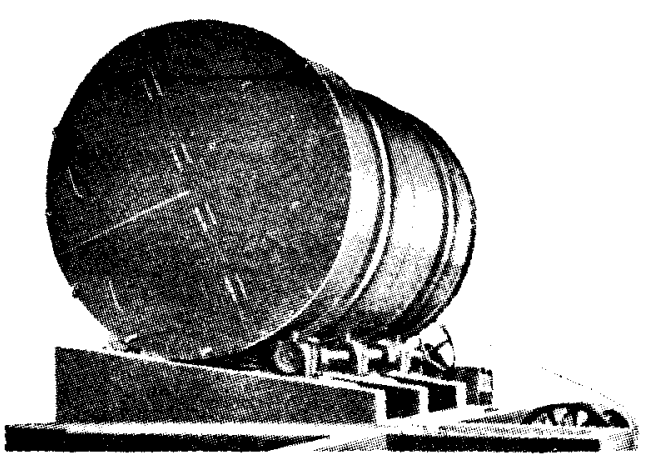

(c) 密閉式湿式ドラムバーカー

第 1 图 各種機械バーカー

$\sim 8.0$ 石 $/ 8$ 時間・人，背板で 0.6 1.5 石 $/ 8$ 時間・ 人, カットバーカーによれば $1.0 \sim 7.0$ 石 $/ 8$ 時間・人, またドラムバーカーについて例示すれば第 3 表の通り

である。

ドラムバーカーの剥皮方式として，水学使用する湿 式，使用しない乾式（しめる程度に使用），また運転 万式として連続，断続の別があり，その豩皮能率もさ まざをであるが，大部分のものは20〜30P のもので 6〜8石/時間である。

乾燥材で䟝皮困難のものは事前に水漬けしてから行 なら方が除麼の点からも好ましい。
第3交 ドラムパーカー実績表

\begin{tabular}{|c|c|c|c|c|c|c|c|}
\hline $\begin{array}{l}\text { 工場 } \\
\text { 名 }\end{array}$ & 原 料 & 径 & 長 & $\mathbf{P}$ & $\begin{array}{l}\text { 剩皮量 } \\
\text { 石/h }\end{array}$ & 備 & 考 \\
\hline A & 枝，小径木 & 8 & 20 & 30 & \multicolumn{2}{|c|}{5.8 湿 } & 式 \\
\hline B & 中 径 木 & 9 & 15 & 30 & \multicolumn{2}{|l|}{7.2} & $" \prime$ \\
\hline $\mathrm{C}$ & 小径 木 & 8 & 8 & 15 & \multicolumn{2}{|c|}{6.5 乾 } & 式 \\
\hline D & 中径木以上 & 10 & 12 & 25 & \multicolumn{2}{|c|}{13.3} & 1 \\
\hline $\mathbf{E}$ & 下䭾廃材 & 7 & 12 & 20 & \multicolumn{2}{|c|}{5.5} & $" \prime$ \\
\hline F & 小 径 木 & 8 & 15 & 30 & \multicolumn{3}{|c|}{6.0 水小量使用 } \\
\hline G & 小径 木 & 6 & 18 & 20 & \multicolumn{2}{|c|}{6.3 湿 } & 式 \\
\hline $\mathrm{H}$ & 小径 木 & 8.7 & 13.5 & 25 & \multicolumn{2}{|c|}{7.0 乾 } & 式 \\
\hline I & & 9 & 40 & 75 & \multicolumn{2}{|c|}{ 20-25 湿式, } & 連続式 \\
\hline
\end{tabular}

註：A〜Hは断続式

パーカーは一機種で全ての原料に万能というわけに

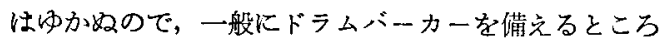
でも，カットバーカー剥き，手剥ぎを併用している。

一般にドラムバーカーで薄物を処理すると, 割れ， 端部の損傷多く、これについてはなお研究すべき問題 がある。またカットバーカーでは梳部まで虽ぎとら れ易い。製材の場合はできる限り，娳皮佼製材するよ らにすべきである。

とも角チップ工場の材料の流れをみると䟝皮工程が 生産量を決定する場合が殆んどであるので，䟝皮施設 とその管理連用は極めて重要である。

第4表 チ ッ ハ - 諸 元表

\begin{tabular}{|c|c|c|c|c|c|c|c|c|}
\hline メーカー & 型 式 & $\begin{array}{c}\text { 円径 盤 } \\
(\mathrm{mm})\end{array}$ & $\begin{array}{l}\text { ナイフ } \\
\text { 枚 数 }\end{array}$ & $\begin{array}{c}\text { ナイフ } \\
\text { 幅(mm) }\end{array}$ & 投 $\underset{(\mathrm{mm})}{ }$ & $\begin{array}{c}\text { 回 転 数 } \\
(\mathrm{rpm})\end{array}$ & $\begin{array}{c}\text { 使 用 } \\
\text { モ一タ- } \\
(\mathrm{HP})\end{array}$ & 能 石 $/ \mathrm{h}$ \\
\hline \multirow{5}{*}{$\mathbf{S}$} & 52 & 1,320 & 6 & 290 & $240 \times 180$ & 420 & 75 & $50 \sim 63$ \\
\hline & 48 & 1,220 & 6 & 240 & $210 \times 165$ & 420 & 40 & $13 \sim 19$ \\
\hline & 40 & 1,000 & 4 & 190 & $165 \times 120$ & 450 & 30 & $8 \sim 9$ \\
\hline & 36 & 900 & 4 & 160 & $140 \times 100$ & 500 & 20 & $3 \sim 5$ \\
\hline & 34 & 600 & 3 & 120 & $100 \times 80$ & 600 & 7.5 & $2 \sim 3$ \\
\hline \multirow{7}{*}{ G } & 1300 & 1,220 & $6 \sim 8$ & 250 & $145 \times 200$ & $400 \sim 500$ & $40 \sim 50$ & $9 \sim 15$ \\
\hline & 1200 & 1,016 & $4 \sim 6$ & 230 & $125 \times 195$ & $450 \sim 550$ & 30 & $6 \sim 12$ \\
\hline & 900 & 915 & $4 \sim 6$ & 190 & $110 \times 150$ & $500 \sim 600$ & $20 \sim 30$ & $5 \sim 9$ \\
\hline & 800 & 762 & $3 \sim 4$ & 165 & $85 \times 125$ & $500 \sim 600$ & $15 \sim 20$ & $5 \sim 8$ \\
\hline & 700 & 660 & 3 & 130 & $85 \times 115$ & $550 \sim 650$ & $10 \sim 15$ & $4 \sim 5$ \\
\hline & 600 & 610 & 3 & 130 & $70 \times 90$ & $550 \sim 700$ & 10 & $3 \sim 4$ \\
\hline & 500 & 508 & 3 & 105 & $65 \times 85$ & & $5 \sim 7.5$ & $2 \sim 2.5$ \\
\hline \multirow{4}{*}{$\mathrm{T}$} & 48 & 1,160 & 6 & 270 & $235 \times 115$ & 400 & 30 & 9 \\
\hline & 36 & 914 & 4 & 170 & $148 \times 80$ & 550 & 20 & 5 \\
\hline & 30 & 762 & 3 & 140 & $120 \times 65$ & 600 & 15 & 2.5 \\
\hline & 20 & 510 & 3 & 125 & $100 \times 70$ & 600 & 10 & 2 \\
\hline \multirow{3}{*}{ A } & SM-3 & 1,100 & 8 & & $200 \times 200$ & 420 & $75 \sim 100$ & $13 \sim 31$ \\
\hline & SM-2 & 950 & 6 & & $90 \times 160$ & 420 & $25 \sim 30$ & $6 \sim 13$ \\
\hline & SM-1 & 600 & 4 & & $70 \times 120$ & 600 & $7 \sim 5$ & $2 \sim 3$ \\
\hline
\end{tabular}


今後剝皮機の主体と考兄られるドラムバーカーにつ いて廃材用として特に工夫された点虫，小型で剥皮能 力を上げて和る点で，これは能力を決定する因子（落 差, 内部構造, 回転数) 中特に内部構造を改良したこ とは主なるのである。また乾式, 移動式ドラムバーカ 一等も廃材チップ工業が新たに生み出したものである。

\section{3. チップの製造}

剥皮した材は，チッパーによりチップ化され，チッ プスクリーンにより起別して適当テップを得ることが できる。

小径木, 加工廃材を対象としては, 通常のロッグチ ッパーで浪質（サイズと形状の点において）のチッ プは得難い。それは一般に投入口断面積に対して, 材 料の断面皘少なく，軽量であるため，投入口中での材 の跳りが多く，激しくなるためである。従って今日チ ップ、場で使用するものはこの点を改良した小型のも のである。しかしそれでるな蛙一般ロッグチッパーに 比較してスリーバー，ダストはやや多い。これは原料 の廃材薄板が多いのでやむを党ない。

チッパーについて諸元，実績および写真を示すと第 4 表, 第5 表㧍よび第 2 図の通りである。

第5表 チッパー能力の実績表

\begin{tabular}{|c|c|c|c|c|}
\hline xーカー & 型式 & 原 & $\overrightarrow{\mathbf{P}}$ & 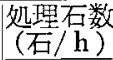 \\
\hline C & 900 & ブナ床板工場廃材 & 20 & 5 \\
\hline A & SM-2 & $\checkmark$ & 35 & 13 \\
\hline A & " & 製材工場廃材 & 30 & 12 \\
\hline S & 48 & 林 地 廃 材 $(L)$ & 40 & $7.5 \sim 15$ \\
\hline$S$ & $" \prime$ & 製材工場廃材 $(\mathrm{N})$ & 40 & 10 \\
\hline $\mathrm{C}$ & 800 & 製材及林地廃材 $(N)$ & 15 & 4 \\
\hline S & 24 & 上 & 7.5 & 3 \\
\hline C & 800 & マッチ小径木 & 15 & 8 \\
\hline $\mathrm{T}$ & 48 & 大 型 割 材 & 50 & $10 \sim 12$ \\
\hline $\mathrm{T}$ & 48 & 製材工場廃材 & 50 & $10 \sim 12$ \\
\hline
\end{tabular}

同一チッパーでも樹種，形状，作業法などによって 実績は交ってくる。第 5 表はフルルチャージした場合 の值である。連続運転の場合にはこれより少る。

またチッパー普及率をみると 36 年 9 月現在で次の ようになっている。

これ性年間生産能力(チップ原料が十分にある場合) としてみると約 $10,000,000 \mathrm{~m}^{3}$ と推定される。

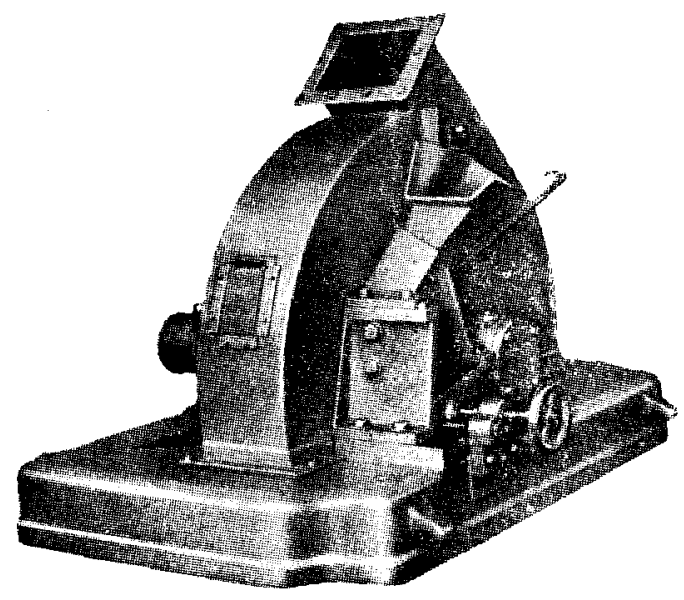

(a) 固定式チッパー

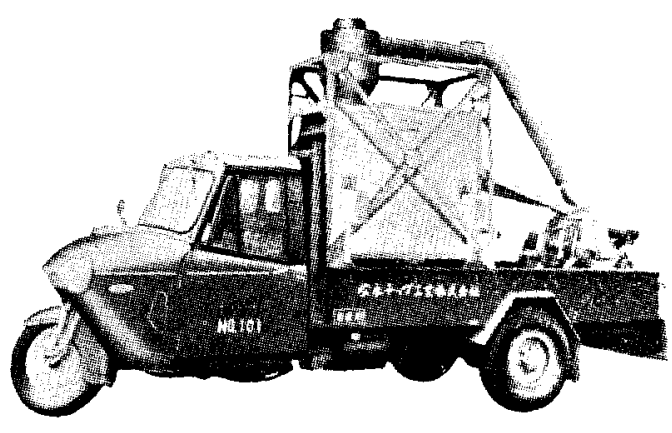

(b) 移動式チッパー

第2図 テッパー各種

最近のチッパーを 31 年頃のものと比䡆すると，構 造, 能力等が著しく改善され，一応安定した内容をも つに至ったようにみ文る。近华は小型（円船径 24" 以 下の）のものが比烄的多量汇骨及してきて找り，原材 料の小形化，集約化をうかがうことができる。また移 動に偍利なようにしたポータプルチッパー（可搬型） も，林地残材処理用として注目されてきた。特殊なる のに単板屑専用のシリンダー型チッパー, 代用チッパ ーとしてェンシレージカッター等を使用している工場 もかる。

次にチップスクリーンヘ進む。

スクリーンる小型で, 回転および振動の 2 鋫類あり, 一般にスクリーンの目は2段で, 粗目は 33〜 35 mm, 細目は 3〜5 $\mathrm{mm}$ である。小規模工場では回転篩が

\begin{tabular}{|l|l|l|c|}
\hline チッパー円艋直径 $(\mathrm{mm})$ & 500 以下, $550 \sim 600,650 \sim 700,750,900,1000,1200$, その他 & 就 \\
\hline 台 & 数 & $347,1154,155,368,806,252,234,205$, & 3521 \\
\hline 割 & 合 (概数) $\%$ & $10,32,4,11,23,7,7,6$, & 100 \\
\hline
\end{tabular}




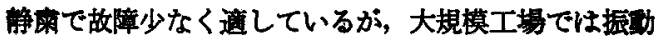
箁の方が能率上好重しい。

チップスクリーンの代表的なるのの諸元と外㭷を示 すと第 6 表，第 3 図の通りてある。

第6表チップスリーン諸元表例

\begin{tabular}{|c|c|c|c|c|c|c|c|}
\hline \multirow{2}{*}{ 型 } & \multirow{2}{*}{$\begin{array}{c}\text { スクーソ寸法 } \\
(\mathrm{mm})\end{array}$} & \multirow{2}{*}{$\begin{array}{c}\text { 畕クリーン 転 } \\
\text { (rpm) }\end{array}$} & \multirow{2}{*}{${ }_{(\mathbb{I})}$ 力 } & \multicolumn{2}{|c|}{ 目 $(\mathrm{mm})$} & \multirow{2}{*}{ 能 } & \multirow{2}{*}{$\begin{array}{l}\text { 振 } \\
(\mathbf{m ~ m})\end{array}$} \\
\hline & & & & 粗 & 密 & & \\
\hline \multirow{3}{*}{$\begin{array}{l}\text { 回 } \\
\text { 軗 } \\
\text { 式 }\end{array}$} & $760 \times 2,260$ & 17 & 1 & $32 \sim 40$ & $4.5 \sim 5$ & $15 \sim 20$ & - \\
\hline & $915 \times 3,000$ & 15 & 2 & $"$ & " & $40 \sim 70$ & - \\
\hline & $1,230 \times 3,636$ & 13 & 3 & " & $"$ & $70 \sim 120$ & - \\
\hline \multirow{3}{*}{$\begin{array}{l}\text { 擩 } \\
\text { 式 }\end{array}$} & $460 \times 1,510$ & 550 & 1 & 32 & 4 & $15 \sim 25$ & 10 \\
\hline & $770 \times 1,830$ & " & 2 & $32 \sim 40$ & $4 \sim 6$ & $25 \sim 100$ & 10 \\
\hline & $1,000 \times 3,000$ & $"$ & 3 & $32 \sim 45$ & $4 \sim 6$ & $75 \sim 150$ & 10 \\
\hline
\end{tabular}
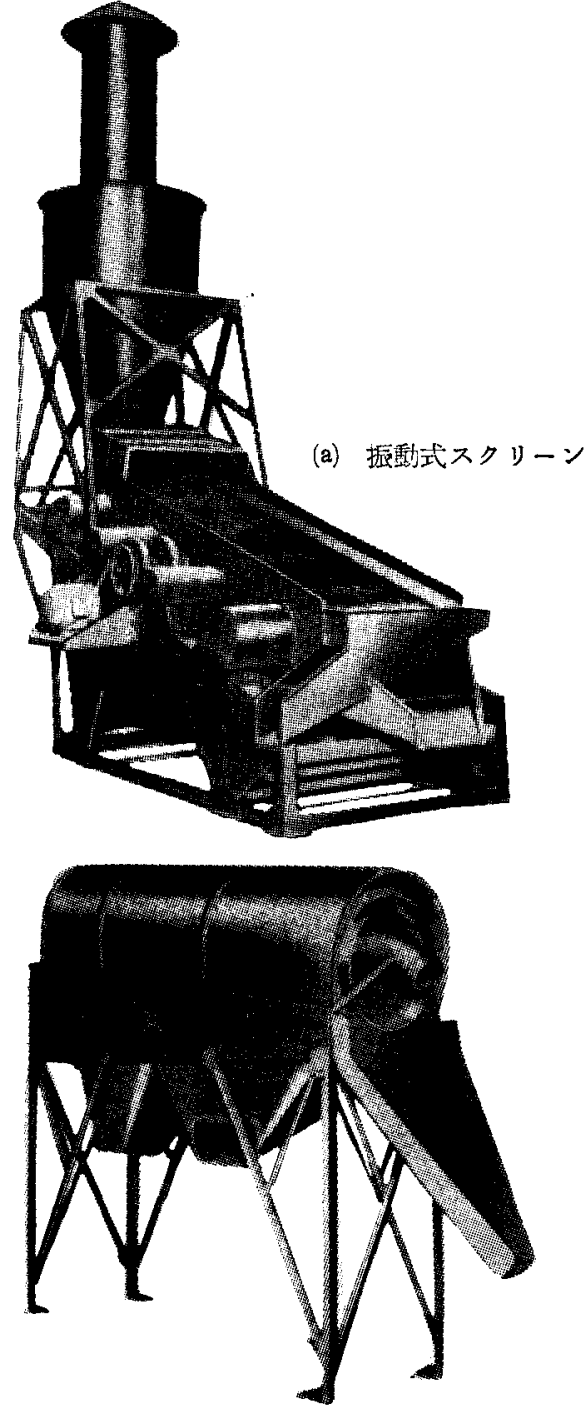

(b) 回転式スクリーン

第3图チップスクリーン
一般にはスクリーン首（主にダスト）の量は 3〜5 \%である。粗大片は再びチッパーに戻すか，特にチッ プクラッシャーで細片化する。

チップサイズは需要工場によって差異がするが, 長 さ 20 , 幅 $20 \sim 30 \mathrm{~mm}$, 厚さ $3 \sim 10 \mathrm{~mm}$ 程度で，実際 には節分試験によって示している。例竞ば某 B・KP工 場では， $6 \mathrm{~mm}$ および $40 \mathrm{~mm}$ 目の節の金網からもれ， また溜をるダスト执よ゙スリバーをそれぞれ 1\%以 内と規定している。スクリーンを出た良チッブは袋詰 め輸送の場合には值ちに袋詰して倉庫に貯えるが，バ ラ積み輸送の場合には一旦簡易なチップサイロに堆積 して，その底部に設けた取出口から，トラックにパラ 積みして輸送する。

\section{4. 輸送}

チップの見掛け容程は，原料の実材積の約 3 倍に増 大する。このカサ高い物を経済的に運搬することはコ スト上重大なことである。

チップ工業の初期には全部麻袋詰めで輸送していた。 従ってどのようにしたらより多くのチップを同一容量 の運搬草に積み込み され，今日ではトラックでは袋積みがバラ積みに優り， 貨車ではバラ積みの方が優ると言われている。

贷輸送では袋詰めおよび開放に手数を要し，垡の機 峨的执よび腐れによる損耗を考えると，多少バラ積み より多く積えですコスト的に不利である。袋輸送は納 入先の受入れ設備が゚゙ラ受入れのできてない瑒合や， トラックがチップ専用にできないような場合括よび， 異樹種チップの混載等に限られ，次にバラ輸送化しつ つある現状である。

バラ積みの場合の積載方法は大体チップを重力によ って車に落す方法がとられていて，一般に建物の 2 階 の床に落し口を設け 1 階に車を固いて落している。こ の場合チップの落し方（単位時間に落し口の単位断面 
積を通過するチップの量) の如何により単位体積当り の充てん率が異ってくる。この落し方が急激な活ど充 てん率は少なくなる。理想としてはチップ相互が遊離 して，1個のチップが落下して，それが完全に落ちつ いてから次のチップが落ちるょうな落し方が好ぬしい。 実際には速かに積戴することに心がけるため最大速度 で落している。これではチップ相互にトラスを生じて 充てん率が雭くなる。この点について機械的な充てん 機の上うなものの工共要する。

バラ輸送の場合には事の走行につれチップ容䖽は次

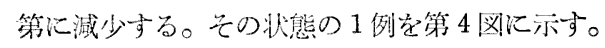

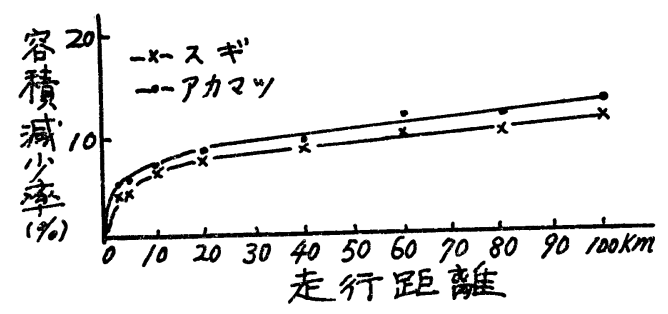

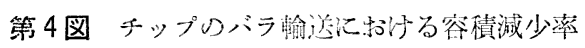
この实騟は完全鋪装の 1 級国道で行なったるので, 規則的汇変化し, 沈下の著しい距離は約 $20 \mathrm{~km}$ 末で であった。实祭には距離のほか洛面状態によっても 左右される。大体 7 〜 $10 \%$ 榀度の容䅡減少率となって いる。バラ翰送は車の外周を板囲いしたものと，金網 四いのものとあるが前省の方が埃が入りにくい。

つぎに鉄道货車拉よびトラックによる䅡載量を第 7 表に示す。

袋, バラともに同一トン数で此較すれば汪とんど差 はなく, むしろ会社别曝載法の差のおが大きいようで 岁る。

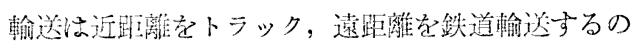
が一般で患るが，これは距離以外の伢情によって 300 $\mathrm{km}$ 位の䞗距踓でもトラックによっている場合も㣻る。

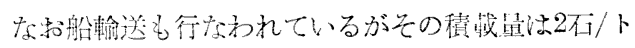

第7表 積 載量実 例 その 1 袋 積 み

\begin{tabular}{|c|c|c|c|}
\hline 車 & 種 & トン 数 & 積 戴 量(石) \\
\hline 鉄 & 道 & 15 & $42 \sim 52$ \\
\hline ト & ラ ック & 5 & $18 \sim 32$ \\
\hline & " & 6 & $30 \sim 33$ \\
\hline & "1 & 8 & $35 \sim 38$ \\
\hline
\end{tabular}

その 2 バラ積み

\begin{tabular}{|c|c|c|c|c|}
\hline 車 & 程 & r ン 数 & 積 & 載 量(石) \\
\hline \multirow[t]{4}{*}{ 鉄 } & 道 & 10 & \multicolumn{2}{|r|}{$32 \sim 50$} \\
\hline & " & 15 & \multicolumn{2}{|r|}{$41 \sim 60$} \\
\hline & " & 17 & \multicolumn{2}{|r|}{60} \\
\hline & " & 35 & \multicolumn{2}{|r|}{100} \\
\hline \multirow[t]{4}{*}{ r } & ラッ & 2 & & $8 \sim 11$ \\
\hline & $"$ & 4 & & 26 \\
\hline & $"$ & 6 & & 30 \\
\hline & " & 8 & & $35 \sim 49$ \\
\hline
\end{tabular}

ン程度である。

\section{5. 検収}

つぎにチップが需要工場で受入れられる場合ぞのよ うにして行なわれるか，いわゆる検収の間題にふれて みよう。チップ取引きは以前は全部容䅡（石）建で行 なっていたが近年重量 $(\mathrm{kg})$ 建もかなり多くなってき ている。このチップの容積案なは重量をどの上うにし て求めるかが検収上重要な間題でめって，これについ て实態打よびその良否をのべてみたい。

検収によって重量を求めるのる重量法, 容量学求め るのを容積法に区分できる。

\section{1 重 量 法}

これは一般に全重量を湘定し，サンプルについて含 水率を検定し, 全絶乾量を求める方法である。

この方法で最も重要な点はサンプリングの間題で心

第 8 表 チップ含水乷のバラッキ（䋓乾法汇よる）

\begin{tabular}{|c|c|c|c|c|c|c|}
\hline 料 & a & b & c & d & $\mathrm{e}$ & f \\
\hline 種 & L材混今 & N材 (ソ速產) & アカマツ & アカマツ & L材混合 & L 忉混合 \\
\hline 取 & 35.12 & 35.12 & 35.12 & 36.2 & 35.10 & 36.2 \\
\hline ロットの大きさ & トラック $(8 \mathrm{t})$ & トラック $(6 \mathrm{t})$ & トラック $(6 \mathrm{t})$ & トラック $(7 \mathrm{t})$ & トラック $(5 \mathrm{t})$ & トラック $(6 \mathrm{t})$ \\
\hline インクレメント（絶乾） & 約 $300 \mathrm{~g}$ & 約 $250 \mathrm{~g}$ & 約 $300 \mathrm{~g}$ & 約 $500 \mathrm{~g}$ & 約 $250 \mathrm{~g}$ & 約 $500 \mathrm{~g}$ \\
\hline イン゙”レメン゙ト数 & 16 & 18 & 18 & 10 & 21 & 10 \\
\hline 算術平均潗偏 & $43.54 \%$ & 57.40 & $\begin{array}{r}46.97 \\
388\end{array}$ & $\begin{array}{r}55.96 \\
100\end{array}$ & $\begin{array}{r}36.45 \\
4.97\end{array}$ & $\begin{array}{r}45.35 \\
0.59\end{array}$ \\
\hline 動 & $3.15 \%$ & 5.23 & 8.26 & 1.80 & 13.70 & 1.30 \\
\hline 最 小值 最大値 & ${ }^{4} 43.27 \sim 44.51$ & $53.70 \sim 61.27$ & $42.49 \sim 51.97$ & $54.36 \sim 57.45 \mid$ & $27.8 \sim 46.0$ & $43.95 \sim 46 . C 0$ \\
\hline
\end{tabular}


る。インクンメント量, その個数, 採取方法等が工場 每に異っているため䇠単にはのべられないが概して少

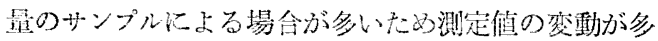
く，その結果取引上のトラブルを起し不信を買ってい る場合が双られる。

抽出したインクレメントの含水率測定治多くは電熱

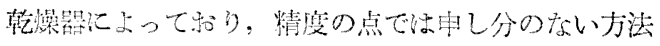

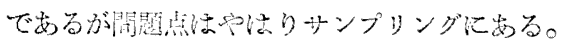

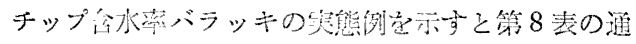
りで发る。

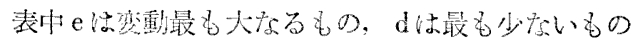

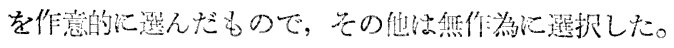
このデータから目標精度（求められた含水率の精度）

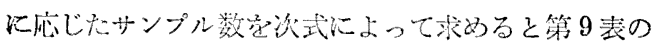
通りである。

$$
\begin{aligned}
& N=\left(\frac{2 \times C V}{\mathrm{E}}\right)^{2} \\
& \text { 但し } N=\text { サンプル数 } \\
& C V=\text { 変動係数 } \\
& E=\text { 目標精度 }
\end{aligned}
$$

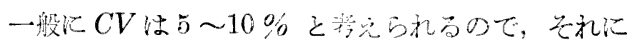

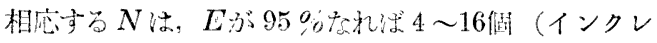

\begin{tabular}{|c|c|c|c|c|c|c|}
\hline 試 料 & a & b & c & d & $\mathrm{e}$ & $f$ \\
\hline $\begin{array}{l}\text { 含水萃の } \\
\text { 㝠辞係数 }\end{array}$ & $3.15 \%$ & $5.23 \%$ & $8.26 \%$ & 1.80 & $13.70 \%$ & $1.30 \%$ \\
\hline 目橒精度 & $95 \%$ & 95 & 95 & 95 & 95 & 95 \\
\hline 抽计個数 & 3 & 4 & 11 & 1 & 30 & 1 \\
\hline 目標精度 & $90 \%$ & 90 & 90 & 90 & 90 & 90 \\
\hline 抽仙個数 & 1 & 1 & 3 & 1 & 8 & 1 \\
\hline
\end{tabular}

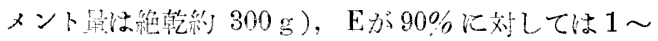

第 9 表 含水率バラッキと含水率測定のための抽 出個数

註）試料，インクレメント等については表1と同じ。 4 個で十分といらことになる。但し実際には然作意抽 出の前提条件が不満足で岕ったり, 異常 $C V$ のロッ トについてる同一条件で行ったりするために非常識の 結果がでる場合があって間題となり，本法全体が悪い ような印象索与克ている。

かようにして含水率が求められるが，チップ総重量 とから総絶乾量が算出学れる。

次に単価が重量単価 (円 $/ \mathrm{kg})$ であるなら，この総絶 乾重量を求め終ればよいので㐫るが, 容積単洒(用/石)

\begin{tabular}{|c|c|c|c|c|c|c|c|c|c|}
\hline 地 & 区 & 公社 & $\checkmark$ & スギ・ヒノキ & モミ・ツガ & エゾ・トド & そ ${ }_{N}^{O}$ 他 & ラワン & $\begin{array}{c}\text { その 他 } \\
\mathrm{L}\end{array}$ \\
\hline \multirow{3}{*}{ 東 } & \multirow{3}{*}{ 北 } & A & 125 & 105 & 115 & 125 & & & 145 \\
\hline & & $B$ & $125 \sim 130$ & 100 & & & & & \\
\hline & & C & 124 & 101 & 124 & 105 & & & 146 \\
\hline \multirow{3}{*}{ Pro } & \multirow{3}{*}{ 重 } & A & 125 & 105 & 115 & 107 & & & 145 \\
\hline & & $\mathrm{B}$ & 130 & & & & & & \\
\hline & & C & 135 & & & & & & 145 \\
\hline \multirow{5}{*}{ 束 } & \multirow{5}{*}{ 源 } & A & 135 & $109 \sim 120$ & $116 \sim 125$ & & & 145 & 145 \\
\hline & & B & 130 & 109 & $113 \sim 116$ & 105 & & 145 & 145 \\
\hline & & C & 185 & 106 & 117 & 117 & 135 & & 145 \\
\hline & & D) & 135 & 125 & 125 & & & & \\
\hline & & $E$ & 130 & 103 & & & 109 & & 145 \\
\hline \multirow{4}{*}{ 近 } & \multirow{4}{*}{ 垥 } & A & 139 & & & & & & \\
\hline & & $B$ & 130 & 112 & & & & . & \\
\hline & & C & 125 & 125 & & & & 130 & 150 \\
\hline & & $\mathrm{D}$ & $130 \sim 185$ & 125 & $115-130$ & & & & 150 \\
\hline \multirow{3}{*}{ 中 } & \multirow{3}{*}{ 国 } & $A$ & 135 & 105 & 135 & & & & \\
\hline & & B & 145 & 115 & & & & & 180 \\
\hline & & A & 130 & 105 & 130 & & & & \\
\hline \multirow[t]{2}{*}{ 九 } & \multirow[t]{2}{*}{ 州 } & $\mathrm{B}$ & 185 & 105 & 125 & & & & 160 \\
\hline & & (: & 135 & 105 & 135 & & & & 160 \\
\hline
\end{tabular}

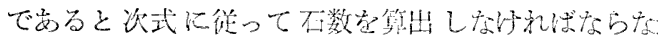
い。

第 10 表 樹種別会社別チップ緦乾比重調 (kg/不) 


$$
\text { 木材チップ エ 業 }
$$

第 11 表 チップ絶乾比重（容積密度数）剆定値（弾位 $\mathrm{kg} /$ 石）

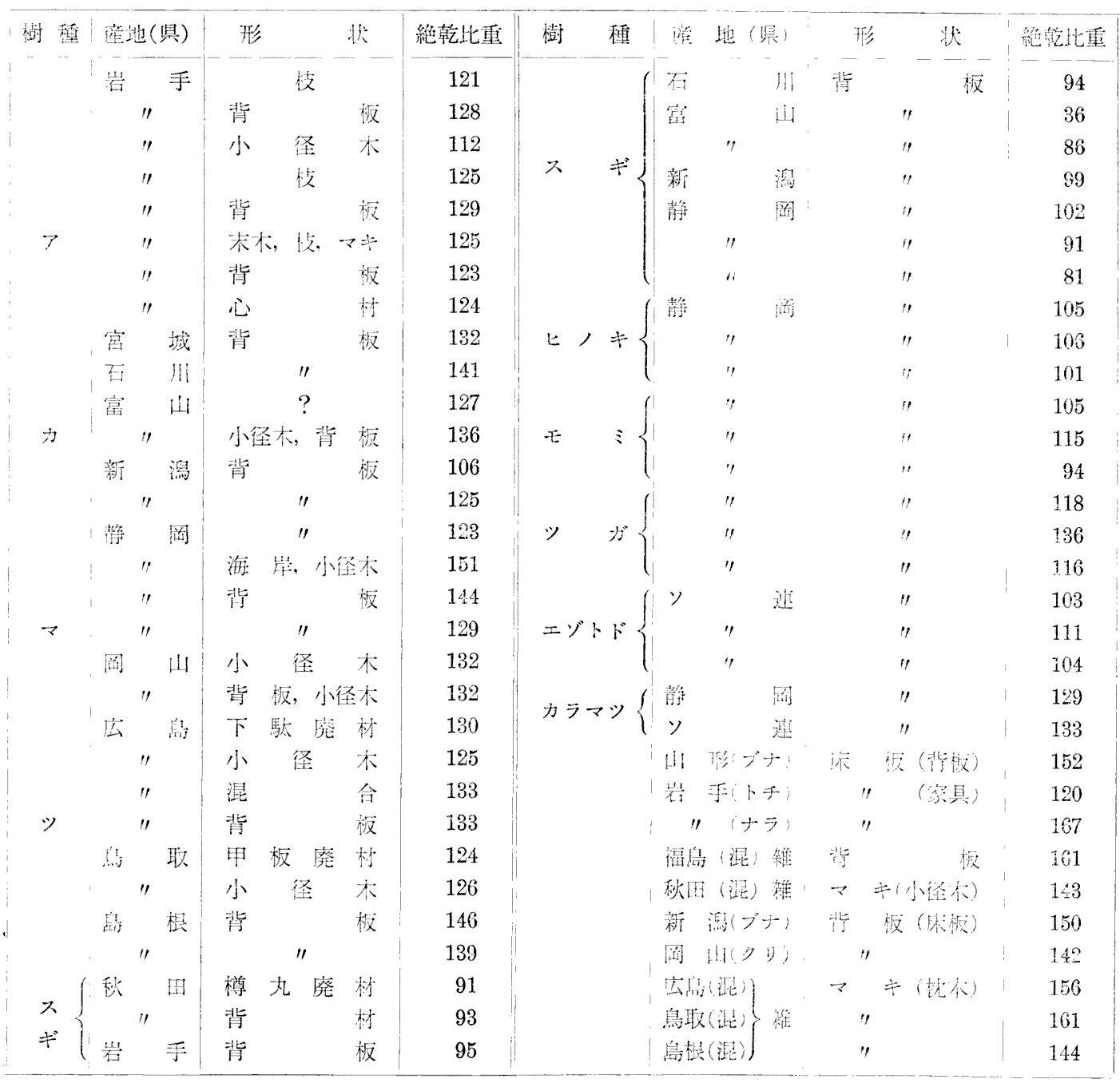

$$
\text { 石 }=\frac{\text { 総絶乾垔量 }(\mathrm{kg})}{\text { 絶乾比垔 }(\mathrm{kg} / \text { 石 })}
$$

ここにいう絶暉比重の意味は次の通りである。

䋓乾比画 $(\mathrm{kg} /$ 石 $)=$ 容積密度数 $(\mathrm{kg} /$ 石 $)$

二絶䩪重量 $\mathrm{kg} /$ 生材 10 尺 ${ }^{3}$

この絶乾比重は樹程, 立地, 経級, 部位等によって 真るものであるが第 10 表は各工場の採用値を示した るのである。とも角工場によってまちまちである。

これらの值の決定に当っては，単に既往の文献から 拾ったもの, 実測に基づくもの等まちまちである。また 石そのものが実石でなく平石基準のものもあって比蓣 が難しい。ともかく同じマッであっても $120 \sim 145 \mathrm{~kg} /$ 石のかなりな幅をもっている。

われわれが测定したチップ工場サンプルについての データをあげると第 11 表の通りである。

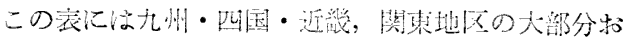
よび北海道地区盆んでいないが，アカマッの文のデ

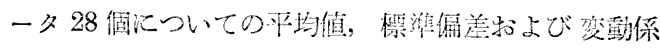
数を算忛すると128.3土7 kg/不，5.47\%となった。こ の変動䋆数からみると想像したより分布が焦中してい た。これはチップの埸合材料がよく混会されて平均化 の機会が多いためであらう。このことは将来この测定 が全国的に終了乙九時には，全国的に间一樹稙につい ては1つの絶乾比重にすることも, 取引海簡素化する

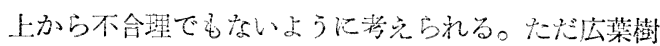
の場合に数地区にしなければならないかもしれない。

\section{2 容 皘 法}

これには見掛け容積すなわち層積を测定する層積法 と実積法とめる。

層 積 法 


米 沢 保 正

第 12 表 容積（層積測定）検取の石換算係数

\begin{tabular}{|c|c|c|c|c|c|c|}
\hline \multirow{2}{*}{ パルプ工場 } & \multirow{2}{*}{\multicolumn{2}{|c|}{ 所在地 }} & \multirow{2}{*}{ 樹 種 } & 輸 & 此 & \multirow{2}{*}{ 備 考 } \\
\hline & & & & 0 & 輸送する場合 & \\
\hline \multirow{2}{*}{ A } & 愛 & 公 & $\mathrm{N}$ & $0.85 \mathrm{~m}^{3}\left(=30.6\right.$ 尺 $\left.^{3}\right)$ & $0.76 \mathrm{~m}^{3}\left(=31\right.$ 尺 $\left.^{3}\right)$ & 正石単位 \\
\hline & & 사 & L & $0.76 \mathrm{~m}^{3}\left(=27.36\right.$ 尺 $\left.^{3}\right)$ & $0.78 \mathrm{~m}^{3}\left(=28.08\right.$ 尺 $\left.^{3}\right)$ & $\prime \prime$ \\
\hline B & 富 & 山 & $\mathrm{N}$ & 31 尺 $^{3}$ & & " \\
\hline C & 長 & 野 & L & 31 尺3 $^{3}$ & & $\prime \prime$ \\
\hline D & 北 海: & 道 & $\mathrm{N}$ & & 30 尺 $^{3}$ (冬季以外) & 平石単位 \\
\hline $\mathrm{E}$ & " & & $\mathrm{L}$ & & 30 尺 $33^{3}$ & $" \prime$ \\
\hline
\end{tabular}

註 正石単位とは 10 尺 $^{3}$ 相当の考え方であり，平石単位とはとの工場の丸太材㛟取（平石）の考方方である。

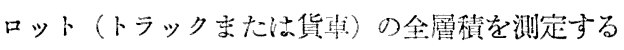
場合とロットからサンプルを抽出して剆定する場合と がある。

全層磧測定はバラ輸送によって到着した需要地に特

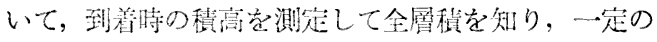

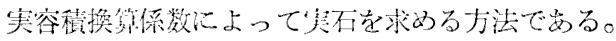

またサンプル抽法で法袋とバラ積みとでやり方が

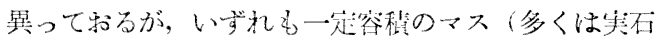
1 石相当のもの）を朋いる焦で同じである。

袋の場合は，マス一杯になるまでの袋数を测定し， それと全袋数とから寒不を求的る。

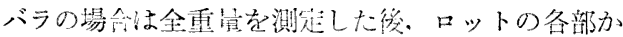
ら少量宛マスに入れ，一杯になった時との重量を測定

して，それと全重量とから寒不を求める。

第 12 表に層䅡と实石との換算係数の実例学示した。 これら層碍梌取に和いては雷量検取に此較して，サ ンプルが極めて多いことが特徽である。このことはサ ンプリングに疑点起生むことが少ない利点がある。し かし换算係数沉ついては事前に十分調查しなければな らない。

\section{実 積 法}

いずれもサンプルによる実容程测定であって，その 実容積測定法としては排水法によっている。

サンプル抽比法としては種々の方法がある。たと党 ば袋箖多なら全袋数の何分の 1 かの抽出した袋の重量 觉測定した後，各袋から $1 \mathrm{~kg}$ 宛 10 個のサンプルを抽 出し，それについて排水量を測定与る。排水量测定に は水是满した容器に，カゴに入れたチップを押し入れ， その溢れる水を $2 l$ のメスシリンダー $(20 \mathrm{cc}$ 目盛)に 受け，その畒積を芜を。それら 10 個の排水量の平均 値と 1 袋平均重量, 総袋数とより全実容皘を求める。

バラ積及なら全重量を测定した後, 一定方法汇従っ て一定量の+ンプルを抽出し，それにつき排水量を前 記同様な方法によって测定し, 計算して全実容積を求 めている。
以上排水法検収で闍題を起したのは比較的低含水率 チップの場合の排水量測定時におけるチップ内への吸 水現象である。实駼によると，かなり高含水染のもの でも（40\%程度でも）比䡥的短時閒飞吸水するもの

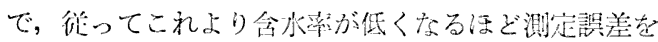
生じ易い。故に本泣については再に改善すべ点があ るように考完る。

一部工場では排水量測定前心予储浸水究 10 分間程 度行なって，一旦水切り（付着水索邀心分離機によっ て行なう）後，排水量学测定している。この方法は排 水量測定法としては偣用してよいと䊅える。

以上各程検取法の概略孛述べたが，いずれが最も良

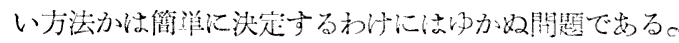
重量検収は製品との閔連性，工悡管理上财ましいので あるが，水分深測定にサンプル量と测定时間の制限を 受け，勢いサンプル量を少なくし，結果について不信 を招き易い。従って今後電父的水分部の上万な榞めて 短時間に实用精度で测定可能のような力法が考案され るまで，むしろ容量法汇席家譲る方が好ましい(現在 電気式水分計が一部代訊験, 実用されているが, その 実用性については未だ結諭するには早過ぎるので差し 控えたい)。すなうち签䅡法中サンプルを大量化抽战 する方法が今日のところでは信用できるので㤝なから らか。

\section{5. チップ生産にともなういろいろの問題}

チップ工業の悩みは䂛意, 排水および樹皮の 3 つで あるとよく言われている。

騒音とはバーカー，チッパ一等の発する音である。 工場地が狭く，住宅地に接近した処ではかなり煊しい。 特にドラムバーカーは著しい。これを防ぐには, 半地 下式にするとか，乾式にして絶縁材料て鑵体を包むと か，防音壁を設けるオ法でかなり騒音を軽減できるが 更に工夫を要する問題である。

排水問題はドラムバーカーよりの排水が，水田，飲 
料水汇害を与光る問題であるが，これの根本的解決法 は排水を出さ妨こである。このため乾式ドラムバー カーが考案されてきた。この場合乾式でも若干は水を 使用するが排水として出る程のものではない。樹皮は 湿った程度で然料などに使用するに便利でもめる。し かし湿式に比較して剝皮に長時間を要することは避け られない。

樹皮は乾燥したものは燃料に利用するが, 湿式のも のは乾燥しないとだめである。收れた变まの利用法と しては, 果樹国や茶畑の敷物に応用して効果をあげて いる。将来は乾式のものと共偟非炭化して成型炭原 料のようなるのに加工利用すべきである。極く一部で

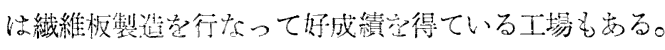

\section{む す び}

完がきにものべたように急速に伸庭したチップ工 業にも生湹技術关のものの間題点を別として原料間題 という大きな間題点が生まれてきている。これは自己

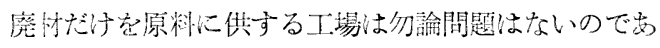
るが，外部よりの購入によって原料をまかなっている

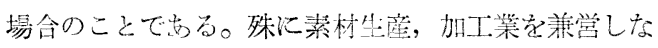
い筧業者汇とって最大な間題となってきている。現在 の設供能力は渦大で，勢い原料の奪い合いをみておる
地域があることである。このような地域については妥 当な規整が必要であろう。

林地残材等の利用については次第に進んできている が，現在のチップ価格では正当な企業利潤が得られず に放って㐫る地区もある。パルプ材俩格の上昇を来さ 始範囲で，チップ価格を若干めげることにより，チッ プの絶刘量を增加させることも可能であり，これはと りも直さずパルプ材の增産に通ずるものとなるので需

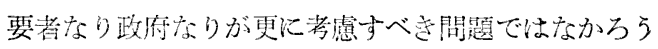
か。

次に検取の間題について現況は需要者の一方的検収 であって，この点について更に合理的な力法の発見， 研究に業界は㓜馀政府当局も介入して統一市べき問題 である。チップ规格についても統一ずざ問題である。 チップ规格についても統一规格を希望する声も垣かれ るここ礼も併せて検䚯ず゙きで心らう。

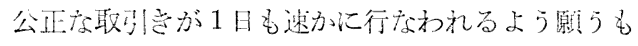
のである。

その他翰送問題等も適切な取計いを旺儿でいる。

要するに今日に物いては, チップ工掌も重要なる産 業であり，それが磨材，低酒值材の利用等国家経済的 意義大であって, 政府当局としても, これらの間題解 決について積椣的㳊努力すべさとではなからうか。 